Www.jmscr.igmpublication.org

Impact Factor 5.84

Index Copernicus Value: 83.27

ISSN (e)-2347-176x ISSN (p) 2455-0450

crossref DOI: _https://dx.doi.org/10.18535/jmscr/v5i7.161

Journal Of Medical Science And Clinical Research

IGM Publication

An official Publication of IGM Publication

\title{
Comparative Assessment of Thoracic Epidural and General Anaesthesia in Modified Radical Mastectomy
}

Author
Dr Rajeev Kumar
Assistant Professor, Department of Anesthesia, Shri Ramkrishna Institute of Medical Sciences \& Sanaka
Hospitals, Durgapur, WB, India
Corresponding Author
Dr Rajeev Kumar
Hospitals, Durgapur, WB, India
Assistant Professor, Department of Anesthesia, Shri Ramkrishna Institute of Medical Sciences \& Sanaka
ABSTRACT
A modified radical mastectomy is a technique in which the whole breast is removed, including the skin,
areola, nipple, and most axillary lymph nodes; the pectoralis major muscle is spared. The study is
conducted in Shri Ramkrishna Institute of Medical Sciences \& Sanaka Hospitals in Surgery department.
The approval of ethical committee had been taken along with the consent from the patients were also
taken. Total 50 patients having are group of $40-70$ year were enrolled in to the study.
Before surgery, all the patients were instructed regarding benefits of thoracic epidural over general
anesthesia by surgeon and the anesthesiologist. General anaesthesia to group B patients having total 25
cases and thoracic epidural was given to patients in group A of 25 patients.
The present study concludes that thoracic epidural anesthesia can be safely and soundly used in women
undergoing modifying radical breast surgeries. The thoracic epidural technique not only provides
hemodynamic stability but also significantly enhances postoperative analgesia and improves overall
satisfaction for patients undergoing modifying radical mastectomy.
Keywords: modified radical mastectomy, general anesthesia, epidural anesthesia.

\section{INTRODUCTION}

A modified radical mastectomy is a technique in which the complete breast is removed, including the skin, areola, nipple, and most axillary lymph nodes; the pectoralis major muscle is spared. Traditionally, a modified radical mastectomy was the principal method of treatment of breast cancer. ${ }^{[1,2]}$ As the treatment of breast cancer evolved, breast conservation has become more widely used. ${ }^{[3,4]}$ However, mastectomy still remains a viable option for women with breast cancer. ${ }^{[5,6]}$
It currently remains the patient's choice to undergo breast conservation or mastectomy with or without reconstruction. The European Organization for Research and Treatment of Cancer 10801 trial found no significant difference in the 20-year overall survival rate between women who underwent breast-conserving surgery and radiation and those who were treated with modified radical mastectomy, for stage 1 or 2 breast cancer. Overall survival at 20 years was $44 \%$ in the breast-conserving surgery group and 
$39 \%$ in the modified radical mastectomy group. Time to distant metastasis also did not differ significantly between the two groups, although the study did find that the 10-year locoregional recurrence of cancer was higher in the breastconserving group than in the mastectomy patients (20\% vs $12 \%$, respectively). ${ }^{[7]}$

There are a few contraindications to breast conservation for which a mastectomy is recommended. According to the National Comprehensive Cancer Network guidelines, [8] indications for mastectomy include the following: Prior radiation therapy to the breast or chest wall Radiation therapy contraindicated by pregnancy (except patients in the third trimester who can receive radiation postpartum)

Inflammatory breast cancer

Diffuse suspicious or malignant-appearing microcalcifications

Widespread disease that is multicentric, located in more than one quadrant, and cannot be removed through a single incision with negative margins

A positive pathologic margin after repeat reexcision and suboptimal cosmetic outcome

Relative indications for mastectomy include the following:

Active connective tissue disease involving skin (eg, scleroderma, lupus)

Tumors greater that $5 \mathrm{~cm}$ in diameter

Focally positive margin

Thoracic epidural analgesia remains a key component of anesthesia-based acute pain services and is used to treat acute pain after: thoracic surgery, abdominal surgery, and rib fractures.1 TEA is warranted when a moderate-to-large thoracic or upper abdominal incision is anticipated. TEA can also be a useful adjunct in fast-track surgery by optimizing pain relief, attenuating the surgical stress response, and allowing early mobilization. TEA using local anesthetic is an important component of fast-track colorectal procedures because it reduces the duration of postoperative ileus.

Thoracic epidural anaesthesia (TEA) has been established as a cornerstone in the perioperative care after thoracic and major abdominal surgery providing most effective analgesia. ${ }^{[8,9]}$ Beyond its analgesic properties, TEA's effects on the postoperative neurohumoural stress response, cardiovascular pathophysiology, and intestinal dysfunction have been in the focus of both clinical and experimental investigations for years. ${ }^{[10-14]}$ However, the use of TEA is related to specific complications and contraindications.

Thoracic epidural allows utilization of incremental doses of local anesthetic agent which offers preservation of the respiratory function. It provides excellent pain relief without impairing respiration.

The technique of thoracic epidural requires special skill and expertise to avoid potential complications like in advertent dural puncture, spinal cord trauma, and epidural hematoma/ abscess.

The present study compared thoracic epidural block and general anesthesia in female patients undergoing breast cancer surgeries with axillary exploration.

\section{METHODOLOGY}

The study is conducted in Shri Ramkrishna Institute of Medical Sciences \& Sanaka Hospitals, Durgapur, in Surgery department. The approval of ethical committee had been taken along with the consent from the patients were also taken. Total 50 patients having are group of 40-70 year were enrolled in to the study. The patients having other infections, Coagulopathy and bleeding disorders were excluded from the study.

Before surgery, all the patients were instructed regarding benefits of thoracic epidural over general anesthesia by surgeon and the anesthesiologist. General anaesthesia to group B patients having total 25 cases and thoracic epidural was given to patients in group A of 25 patients.

Group A:- All patients receiving general anesthesia were pre-medicated with injection glycopyrollate $0.2 \mathrm{mg}$, injection ondanseteron 4 $\mathrm{mg}$ intravenously 60minutes before surgery and 
induced with injection butorphenol $1 \mathrm{mg}$ followed by propofol $2-2.5 \mathrm{mg} / \mathrm{kg}$ intravenously. Tracheal intubation was facilitated using succinylcholine 1$1.5 \mathrm{mg} / \mathrm{kg}$. Anesthesia was maintained using isoflurane along with admixture of oxygen and nitrous oxide. Atracurium $0.5 \mathrm{mg} / \mathrm{kg}$ was administered intravenously for muscle relaxation. Neostigmine $0.05 \mathrm{mg} / \mathrm{kg}$ with glycopyrolate $0.01 \mathrm{mg} / \mathrm{kg}$ were injected intravenously for reversal of neuromuscular blockade. $75 \mathrm{mg}$ of injection diclofenac was administered intravenously for post-operative pain whenever required.

Group B: Thoracic epidural block was performed in sitting position. A18 G Touhy needle was inserted in mid-line at level of T6-7 inter-vertebral space. An epidural catheter was introduced $3-5 \mathrm{~cm}$ into epidural space using Touhy needle. A test dose 2-3 $\mathrm{ml}$ of $2 \%$ Xylocaine with adrenaline 1:200000 was given to exclude the intravascular and intrathecal injection. The catheter was secured and $15 \mathrm{ml}$ of $0.5 \%$ bupivacaine was administered in 5 mlfractions testing the anesthesia level.

\section{RESULTS \& DISCUSSION}

The data from the both the group is collected and presented as below. The gae and sex data is presented in below table.

\begin{tabular}{|c|c|c|}
\hline Groups & $\begin{array}{c}\text { A: General } \\
\text { Anesthesia } \\
\text { Group }\end{array}$ & $\begin{array}{c}\text { B: Thoracic } \\
\text { epidural Group }\end{array}$ \\
\hline Age(yr) & $49-69$ & $48-67$ \\
\hline Male & 30 & 28 \\
\hline Female & 20 & 22 \\
\hline Weight $(\mathrm{Kg})$ & $65-85$ & $61-82$ \\
\hline
\end{tabular}

Table 2: Intraoperative Patients Characteristics

\begin{tabular}{|c|c|c|c|c|}
\hline \multirow{2}{*}{ Characteristics } & \multicolumn{2}{|c|}{$\begin{array}{c}\text { A: General } \\
\text { Anesthesia } \\
\text { Group }\end{array}$} & \multicolumn{2}{c|}{$\begin{array}{c}\text { B: Thoracic } \\
\text { epidural Group }\end{array}$} \\
\cline { 2 - 5 } & $\begin{array}{c}\text { No. of } \\
\text { Cases }\end{array}$ & $\begin{array}{l}\text { Percen } \\
\text {-tage }\end{array}$ & $\begin{array}{c}\text { No. of } \\
\text { Cases }\end{array}$ & $\begin{array}{l}\text { Percen } \\
\text {-tage }\end{array}$ \\
\hline $\begin{array}{c}\text { Axillary } \\
\text { Supplementati } \\
\text { on }\end{array}$ & 1 & 4 & 5 & 20 \\
\hline Sedation & 1 & 4 & 24 & 96 \\
\hline Hypertension & 7 & 28 & 0 & 0 \\
\hline Hypotension & 2 & 8 & 15 & 60 \\
\hline Tachycardia & 1 & 4 & 3 & 12 \\
\hline Bradycardia & 3 & 12 & 10 & 40 \\
\hline
\end{tabular}

Table 3: Postoperative Observation:

\begin{tabular}{|c|c|c|c|c|}
\hline \multirow{2}{*}{ Characteristics } & \multicolumn{2}{|c|}{$\begin{array}{c}\text { A: General } \\
\text { Anesthesia Group }\end{array}$} & \multicolumn{2}{c|}{$\begin{array}{c}\text { B: Thoracic epidural } \\
\text { Group }\end{array}$} \\
\cline { 2 - 5 } & $\begin{array}{c}\text { Number } \\
\text { of } \\
\text { Cases }\end{array}$ & Percentage & $\begin{array}{c}\text { Number } \\
\text { of } \\
\text { Cases }\end{array}$ & Percentage \\
\hline Nausea & 10 & 40 & 3 & 12 \\
\hline Vomiting & 15 & 60 & 3 & 12 \\
\hline Satisfied & 20 & 80 & 23 & 92 \\
\hline
\end{tabular}

Postoperative incidence of nausea and vomiting was more in general anesthesia group.

The practice of thoracic epidural has been increasing in recent years. High thoracic epidural can be used to avoid endotracheal intubation and offers less respiratory complications. Similarly Groeben H. et al studied the effect of high thoracic epidural and local anesthetic on bronchial hyper reactivity and concluded that thoracic epidural is safer than general anesthesia in respiratory compromised patients ${ }^{[15]}$. It can provide adequate anesthesia with minimal effect and without patient discomfort because surgery of breast does not require motor blockade. The incidence of hypotension was high $(60 \%)$ however it was easily controlled by lower dose of vasopressor. Similarly Doss NW, Ipe J, Crimi T et al studied continuous thoracic epidural anesthesia with $0.2 \%$ Ropivacaine versus general anesthesia for perioperative management of modified radical mastectomy and had similar results [16]. Respiration was also not significantly affected demonstrating that thoracic epidural can be safely usedin respiratory compromised patients. Similarly Groeben H, Schuafer B et al studied lung function under high thoracic segmental epidural anesthesia with Ropivacaine or Bupivacaine in patients with severe obstructive pulmonary disease undergoing breast surgery and had similar results ${ }^{[17]}$. The patients undergoing regional anesthesia were discharged earlier than general anesthesia and is more cost effective.

The present study concludes that thoracic epidural anesthesia can be safely and soundly used in women undergoing modifying radical breast surgeries. The thoracic epidural technique not 
only provides hemodynamic stability but also significantly enhances postoperative analgesia and improves overall satisfaction for patients undergoing modifying radical mastectomy.

\section{REFERENCES}

1. Cotlar AM, Dubose JJ, Rose DM. History of surgery for breast cancer: radical to the sublime. Curr Surg. 2003 May-Jun. 60(3):329-37. [Medline].

2. Loukas M, Tubbs RS, Mirzayan N, Shirak M, Steinberg A, Shoja MM. The history of mastectomy. Am Surg. 2011 May. 77(5):566-71. [Medline].

3. Christian MC, McCabe MS, Korn EL, Abrams JS, Kaplan RS, Friedman MA. The National Cancer Institute audit of the National Surgical Adjuvant Breast and Bowel Project Protocol B-06. N Engl J Med. 1995 Nov 30. 333(22):1469-74. [Medline].

4. Fisher B, Montague E, Redmond C, et al. Comparison of radical mastectomy with alternative treatments for primary breast cancer. A first report of results from a prospective randomized clinical trial. Cancer. 1977 Jun. 39(6 Suppl):2827-39. [Medline].

5. Krag DN, Anderson SJ, Julian TB, et al. Sentinel-lymph-node resection compared with conventional axillary-lymph-node dissection in clinically node-negative patients with breast cancer: overall survival findings from the NSABP B-32 randomised phase 3 trial. Lancet Oncol. 2010 Oct. 11(10):927-33. [Medline]. [Full Text].

6. Giuliano AE, Hunt KK, Ballman KV, et al. Axillary dissection vs no axillary dissection in women with invasive breast cancer and sentinel node metastasis: a randomized clinical trial. JAMA. $2011 \mathrm{Feb}$ 9. 305(6):569-75. [Medline].

7. Black DM, Hunt KK, Mittendorf EA. Long term outcomes reporting the safety of breast conserving therapy compared to mastectomy: 20-year results of EORTC 10801. Gland Surg. 2013 Aug. 2 (3):1203. [Medline].

8. Popping DM, Zahn PK, Van Aken HK, Dasch B, Boche R, Pogatzki-Zahn EM. Effectiveness and safety of postoperative pain management: a survey of 18925 consecutive patients between 1998 and 2006 (2nd revision): a database analysis of prospectively raised data. $\mathrm{Br} \mathrm{J}$ Anaesth 2008; 101: 832-40.

9. Royse C, Royse A, Soeding P, Blake D, Pang J. Prospective randomized trial of high thoracic epidural analgesia for coronary artery bypass surgery. Ann ThoracSurg 2003; 75: 93-100.

10. Rodgers A, Walker N, Schug S, et al. Reduction of postoperative mortality and morbidity with epidural or spinal anaesthesia: results from overview of randomised trials. $\mathrm{Br}$ Med $\mathrm{J} 2000 ; 321$ : 1493.

11. Liu SS. Anesthesia and analgesia for colon surgery. RegAnesth Pain Med 2004; 29: $52-7$.

12. Kozian A, Schilling $T$, Hachenberg $T$. Non-analgetic effects of thoracic epidural anaesthesia. Curr Opin Anaesthesiol 2005; 18: 29-34.

13. Liu SS, Wu CL. Effect of postoperative analgesia on major postoperative complications: a systematic update of the evidence. Anesth Analg 2007; 104: 689702.

14. Brodner G, Van Aken H, Hertle L, et al. Multimodal perioperative managementcombining thoracic epidural analgesia, forced mobilization, and oral nutritionreduces hormonal and metabolic stress and improves convalescence after major urologic surgery. AnesthAnalg 2001; 92: 1594-600.

15. Groeben H, Schuager B, Pavlakovic G et al. - Lung function under high thoracic 
segmental epiduralanesthesia with

Ropivacaine or Bupivacaine in patients with severe obstructive pulmonary disease undergoing breast surgery. Anesthesiology. 2002;92:536-541.

16. Ballantyne JC, Carr DB, deFerranti S, Suarez T, Lau J,Chalmers TC, et al. The comparative effects of postoperative analgesic therapies on pulmonary outcome: cumulative meta-analysis of randomized, controlled trail. Anesth Analg 1998;86:589-612.

17. Yeh CC, Yu JC, Wu CT, et al. Thoracic epidural anesthesia for mastectomy. Workard J Surg 1999;23:256-61. 